\title{
Sterilization of heat-labile culture plastic boxes using formaldehyde vapor
}

\author{
Erlei Melo Reis
}

Laboratório de Fitopatologia - Micologia, Faculdade de Agronomia e Medicina Veterinária, Universidade de Passo Fundo, 99001-970, Passo Fundo, RS, Brasil. Bolsista do CNPq.

Autor para correspondência: Erlei Melo Reis (erleireis@upf.br)

Data de chegada: 05/11/2012. Aceito para publicação em: 22/02/2013.

Sterilization of laboratory equipment is essential in microbiological studies. The most common methods that have been routinely used to sterilize glassware and metal material are dry heat $\left(160-180^{\circ} \mathrm{C}\right)$ and water steam in autoclave at $121-134^{\circ} \mathrm{C}$.

Gaseous sterilization is used for sterilizing thermo-labile substances like plastic Petri dishes. Plastic matherial is heat-labile and usually disposable; however, it may be reused after sterilization with ethylene oxide or propylene oxide at room temperature.

The aim of this study was to sterilize plastic Petri dishes and acrylic boxes, using a cheap chemical and without the need of special facilities.

Culture media and fungal colonies, in plastic Petri dishes (6 or $9 \mathrm{~mm}$ diameter) or acrylic boxes ( $11 \times 11 \times 2.5 \mathrm{~cm}$ high), were removed by scraping with a plastic spatula, washed with water plus detergent using a soft sponge, rinsed and allowed to dry on the laboratory bench.

Formaldehyde $\left[\left(\mathrm{CH}_{2} \mathrm{O}\right)_{3}\right]$ (formic aldehyde) was used as a chemical sterilizing agent. The chemical ("Formol 37\%", Quimicamar, Cachoeirinha - RS) was pipetted $(50 \mathrm{~mL})$ into a $250 \mathrm{~mL}$-volume Erlenmeyer on a cotton ball that was inside the flask and absorbed the chemical. The flask was then placed among the dishes/gerboxes on the bottom of a plastic bag. As the liquid turns into gas and requires a certain concentration to sterilize the material, a plastic bag was used to avoid vapor escape. Each batch consisted of 100 individual $6 \mathrm{~mm}$-diameter plates, or 50 individual $9 \mathrm{~mm}$ dishes, and/or 50 gerboxes. The bag was tightly closed with a rubber band and maintained in an environment at temperature $\geq$ $20^{\circ} \mathrm{C}$ for 48 hours. After such time of exposure to the vapor, the plastic bag was partially opened to release the remaining vapor in a fume hood for 12 hours. The bag was closed again with the rubber band and was ready to be used or stored.

Care should be taken not to scratch the plastic containers when washing with a sponge or other abrasive material. In the Laboratory of Plant Pathology - UPF, plastic containers have been sterilized since 2003 and reused for countless time. Following the described routine methodology, no contamination with fungi and bacteria has been detected.

Formaldehyde is a colorless, highly toxic, and flammable gas at room temperature which is slightly heavier than the air. Thus, it should be handled with a gas mask and inside a fume hood. 